\title{
Reduction of Microbial Contamination in Drinking Water using Flocculant Settling
}

\author{
Arshad Ali, Hashim Nisar Hashmi, Ashfaq Ahmad, and \\ Intikhab Ahmad Qureashi
}

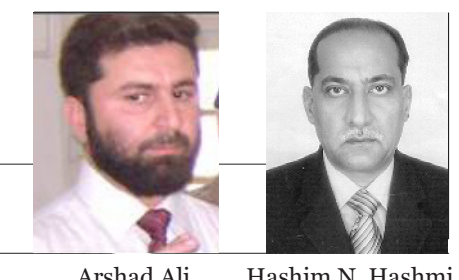

\begin{abstract}
Pakistan is subjected to rapid water shortage due to different social and environmental problems. Moreover, the drinking water is being contaminated at an alarming rate that is mostly due to the discharge of untreated domestic and industrial effluent and agricultural run-off. Therefore, this study was designed to evaluate the water quality problems of the subject area and to determine a cost effective treatment technique. The main objective was to determine the removal efficiency of microbial contamination using flocculant settling. The main pollutants identified by conducting water quality tests are arsenic, fluoride, nitrates and microbial contamination. The maximum concentration of arsenic, fluoride, nitrates and microbial contamination were observed as $12 \mathrm{ppb}, 2.2 \mathrm{mg} / \mathrm{L}, 26 \mathrm{mg} / \mathrm{L}$ and 84 colonies $/ 100 \mathrm{~mL}$, respectively. During discrete settling tests performed in a $12 \mathrm{cft}$ column, it was noticed that the removal of microbial contamination corresponding to a detention time of $225 \mathrm{~min}$ is $26.7 \%$ only. While working on different coagulants, it was observed that the optimum alum, lime and magnesium dosage for the removal of microbial contamination is $31.5 \mathrm{mg} / \mathrm{L}$, $10.5 \mathrm{mg} / \mathrm{L}$ and $27 \mathrm{mg} / \mathrm{L}$ respectively. The final re-sults of the study suggest that the use of lime as a coagulant to improve the quality of water in terms of microbial contamination is an effective and reliable technique, both in terms of its treat-ability performance and cost-effectiveness, which was noticed to be $77.7 \%$.
\end{abstract}

Key words: Water quality, contamination, pollutants, coagulation, coliform, alum, Pakistan

\section{Introduction}

Pakistan's current population of 141 million is expected to grow to about 221 million by the year 2025. This increase in population will have direct impact on the water sector for meeting the domestic, industrial and agricultural needs. Pakistan has now essentially exhausted its available water resources and is on the verge of becoming a water deficit country (WHO and UNICEF n.d.). The per capita water availability has dropped from $5,600 \mathrm{~m} 3$ to $1,000 \mathrm{~m} 3$. The quality of groundwater and surface-water is low and is further deteriorating because of unchecked disposal of untreated munici-pal and industrial waste water and excessive use of fertilizers and insecticides (WHO and UNICEF 2006).

Results from various investigations and surveys indicate that water pollution has increased in Pakistan. The water quality deterioration problems are caused by the discharge of hazardous industrial wastes including persistent toxic synthetic organic chemicals, heavy metals, pesticide products and municipal wastes, untreated sewage water to natural water bodies. In several areas, increased arsenic, nitrate and fluoride contamination was detected in drinking water in addition to microbial contamination (West 2006, Pak-EPA 1999).

Water pollution is a major problem in the global context. It has been suggested that it is the leading worldwide cause of death and diseases and that it accounts for the deaths of more than 14,000 people daily (Nwachcuku and Gerba 2004).
The major water quality problems being faced by Pakistan are microbial contamination, arsenic, nitrates and fluoride contamination. Therefore, this study was designed to evaluate the water quality of the local (subject) zone, and to determine an optimum treatability option for the removing of desirable contaminents. The main objective was to determine the removal efficiency of microbial contamination using sedimentation process.

\section{Material and Methodology}

Various samples from different locations were collected in clean and sterilized bottles, which were then analyzed for major water quality parameters using standards methods (APHA, AWWA \& WEF, 1995). Attempts of reducing the microbial contamination were also conducted by using a laboratory scale plain sedimentation tank within effective volume of $12 \mathrm{cft}$. For the intensification of settling process the most common and cheapest coagulants like lime, alum and magnesium sulfate were used in the study, using "Jar Test Apparatus" (Masters 1998, Lindsten 1984, Holleman and Wiberg 2001).

\section{Results and Discussion}

The results obtained from the physical, chemical and biological analysis of water samples obtained from various sources are tabulated below. The results obtained from the tests indicate that the water quality in most parts of the subject area is polluted in one way or the other. The main pollution identified in terms of microbial, arsenic, nitrates and fluoride. To determine the optimum and feasible treatability solution for the 
water treatment, synthetic samples were made containing the subject pollutants, namely, arsenic, nitrates, fluoride and maximum turbidity for the microbial pollution were added. These samples were then tested first by making trials on plain sedimentation and then by adding various types of coagulants like during the Jar Test to find an optimum treatability solution for them. Namely the coagulants used were alum, lime and magnesium sulfate.

\begin{tabular}{|l|l|l|l|l|l|}
\hline S. No. & Parameter & Unit & Result & WHO & Remarks \\
\hline 1 & $\mathrm{pH}$ & - & 7.4 & $6.5-8.5$ & Within the limits \\
\hline 2 & Temperature & $\mathrm{oC}$ & 20 & -- & -- \\
\hline 3 & Turbidity & $\mathrm{NTU}$ & 3.5 & 5 & Within the limits \\
\hline 4 & Arsenic & $\mathrm{ppb}$ & 12 & 10 & Beyond the limits \\
\hline 5 & Fluoride & $\mathrm{mg} / \mathrm{L}$ & 2.2 & 1.5 & Beyond the limits \\
\hline 6 & Nitrates & $\mathrm{mg} / \mathrm{L}$ & 14 & 10 & Beyond the limits \\
\hline 7 & Total Coilform & $\mathrm{No} / 100 \mathrm{~mL}$ & 16 & Nil & Beyond the limits \\
\hline
\end{tabular}

Table 1: Water Quality Analysis of the Ground Source

\begin{tabular}{|l|l|l|l|l|l|}
\hline S. No. & Parameter & Unit & Result & WHO & Remarks \\
\hline 1 & $\mathrm{pH}$ & - & 10.4 & $6.5-8.5$ & Beyond the limits \\
\hline 2 & Temperature & $\mathrm{oC}$ & 22 & -- & -- \\
\hline 3 & Turbidity & $\mathrm{NTU}$ & 9.5 & 5 & Beyond the limits \\
\hline 4 & Arsenic & $\mathrm{ppb}$ & 7.0 & 10 & Within the limits \\
\hline 5 & Fluoride & $\mathrm{mg} / \mathrm{L}$ & 2.0 & 1.5 & Beyond the limits \\
\hline 6 & Nitrates & $\mathrm{mg} / \mathrm{L}$ & 26 & 10 & Beyond the limits \\
\hline 7 & Total Coilform & No/ $100 \mathrm{~mL}$ & 84 & Nil & Beyond the limits \\
\hline
\end{tabular}

Table 2: Water Quality Analysis of the Surface Source

\begin{tabular}{|l|l|l|l|l|l|}
\hline S. No. & Parameter & Unit & Result & WHO & Remarks \\
\hline 1 & $\mathrm{pH}$ & - & 8.1 & $6.5-8.5$ & Beyond the limits \\
\hline 2 & Temperature & oC & 20 & -- & -- \\
\hline 3 & Turbidity & NTU & 4.8 & 5 & Within the limits \\
\hline 4 & Arsenic & $\mathrm{ppb}$ & 11 & 10 & Beyond the limits \\
\hline 5 & Fluoride & $\mathrm{mg} / \mathrm{L}$ & 1.8 & 1.5 & Beyond the limits \\
\hline 6 & Nitrates & $\mathrm{mg} / \mathrm{L}$ & 13 & 10 & Beyond the limits \\
\hline 7 & Total Coilform & No/100mL & 27 & Nil & Beyond the limits \\
\hline
\end{tabular}

Table 3: Water Quality Analysis of the Tap Source

\begin{tabular}{|l|l|l|l|l|}
\hline \multirow{2}{*}{$\begin{array}{l}\text { Detention Time } \\
(\mathrm{min})\end{array}$} & \multicolumn{4}{|c|}{ Percentage Removal } \\
\cline { 2 - 5 } & Arsenic & Fluoride & Nitrates & Total Coliform \\
\hline 25 & 0.9 & 0.7 & 2.2 & 17.6 \\
50 & 0.71 & 1.4 & 1.4 & 19.7 \\
75 & 1.1 & 1.7 & 0.7 & 21.1 \\
100 & 0.84 & 0.8 & 2.1 & 23.4 \\
125 & 1 & 1.2 & 2.1 & 24.4 \\
150 & 0.65 & 1.4 & 1.9 & 25.1 \\
175 & 0.8 & 1.6 & 2 & 26 \\
200 & 1.3 & 1.1 & 1.8 & 26.8 \\
225 & 1.2 & 0.6 & 2.4 & 26.7 \\
250 & 1.2 & 0.5 & 2.3 & 28.2 \\
275 & 1.4 & 1 & 1.6 & 28.1 \\
300 & 1.5 & 1.3 & 1.8 & 29 \\
\hline
\end{tabular}

Table 4: Result Obtained from the Sedimentation Test
Treatability performance of discrete settling

Since, the water samples from various locations were highly polluted and did not meet the criteria of the WHO drinking water parameters standards, therefore, in the first attempt, the synthetic water sample was tried in a model sedimentation tank of about 12cft. At regular interval of time $25 \mathrm{~min}$, 50min, $75 \mathrm{~min}$, up to $300 \mathrm{~min}$, the percentage removal of arsenic, fluoride, nitrates and microbial contamination were observed and the data obtained is shown in the Table 4.

The minimum arsenic removal efficiency of $0.65 \%$, fluoride removal efficiency of $0.5 \%$, nitrates removal efficiency of $0.7 \%$ and $\mathrm{mi}-$ crobial removal efficiency of $17.6 \%$ were observed at detention time of $150 \mathrm{~min}, 250 \mathrm{~min}$, $75 \mathrm{~min}$ and $25 \mathrm{~min}$, respectively. Whereas, the maximum arsenic removal efficiency of $1.5 \%$, fluoride removal effi-ciency of $1.7 \%$, nitrates removal efficiency of $2.4 \%$ and microbial removal efficiency of $29 \%$ were observed at detention time of 30omin, 75min, 225 min and $300 \mathrm{~min}$ re-spectively. However, the maximum and minimum percentage removal of arsenic, fluoride, nitrates and microbial contamination during the plain sedimentation tests trial does not meet the requirements of WHO drinking water quality standards. Thus it requires advanced or conventional treatment to bring down these various pollut-ants to the desired standard. The optimum removal of arsenic, fluoride, nitrates and microbial contamination at a detention time of $225 \mathrm{~min}$ in a plain sedimentation tank was observed as $1.2 \%, 0.6 \%, 2.4 \%$ and $26.7 \%$ respectively. The percentage removal of arsenic, fluoride, nitrates and microbial contamination is presented in Figures 1-4.

\section{Treatability performance of coagu- lants dosage}

In order to determine the optimum dosage of alum, lime and magnesium sulfate, they were used as coagulants varying in concentration from $4.5 \mathrm{mg} / \mathrm{L}$ to $54 \mathrm{mg} / \mathrm{L}, 1.5 \mathrm{mg} / \mathrm{L}$ to $18 \mathrm{mg} / \mathrm{L}$ and $3.0 \mathrm{mg} / \mathrm{L}$ to $36 \mathrm{mg} / \mathrm{L}$ respectively. Figures 5-7 illustrate the effects of different coagulants of the removal of microbial contamination from drinking water.

The minimum microbial contamination removal by using alum, lime and magne-sium sulfates were observed as $22.1 \%, 61.2 \%$, and $18 \%$ respectively. Whereas, the maximum microbial contamination removal by using alum, lime and magnesium sul-fates were observed as $54 \%, 77.7 \%$ and $28.8 \%$, respectively. The optimum dosage of alum, lime and magnesium sulfates for the removal of microbial contamination was observed as $31.5 \mathrm{mg} / \mathrm{L}, 10.5 \mathrm{mg} / \mathrm{L}$ and $27 \mathrm{mg} / \mathrm{L}$ respectively. 

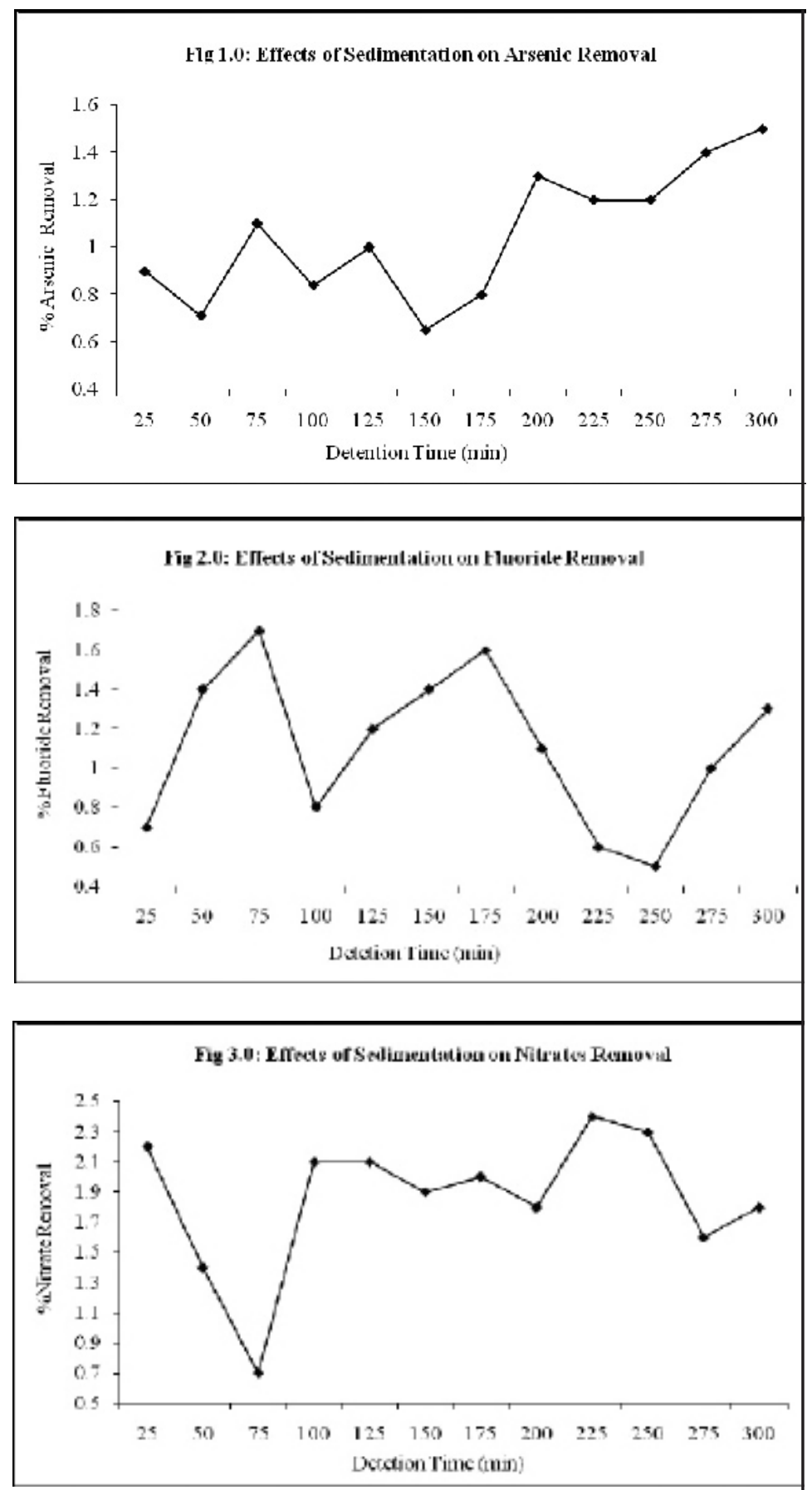

Fig 4.0: Effects of Sedimentation on the Total Collform Removal

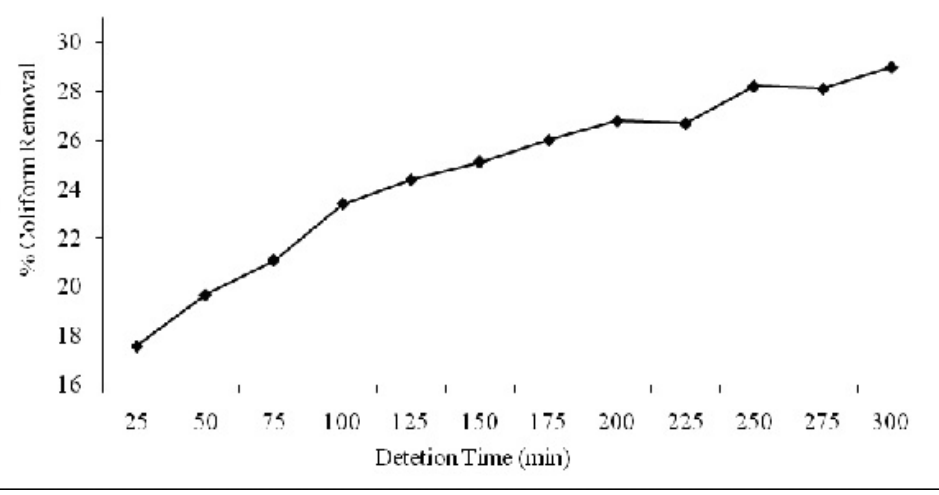




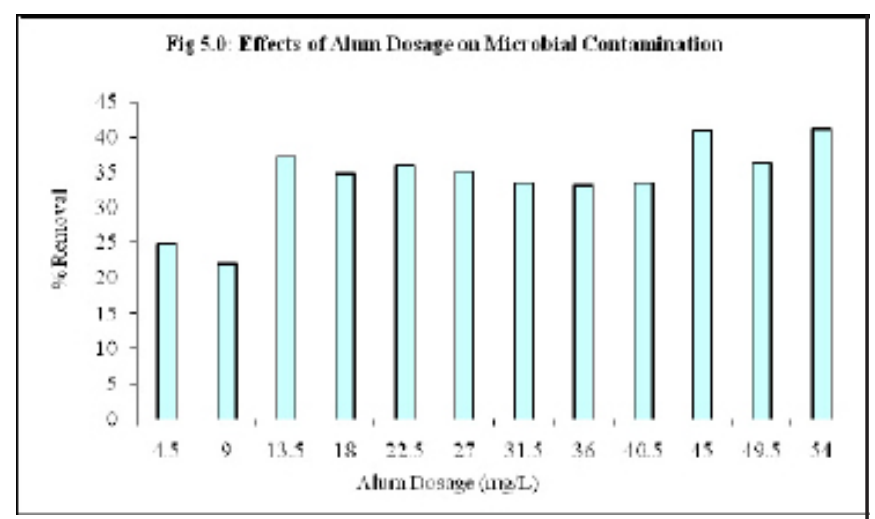

A long-term study is required to carry out the complete
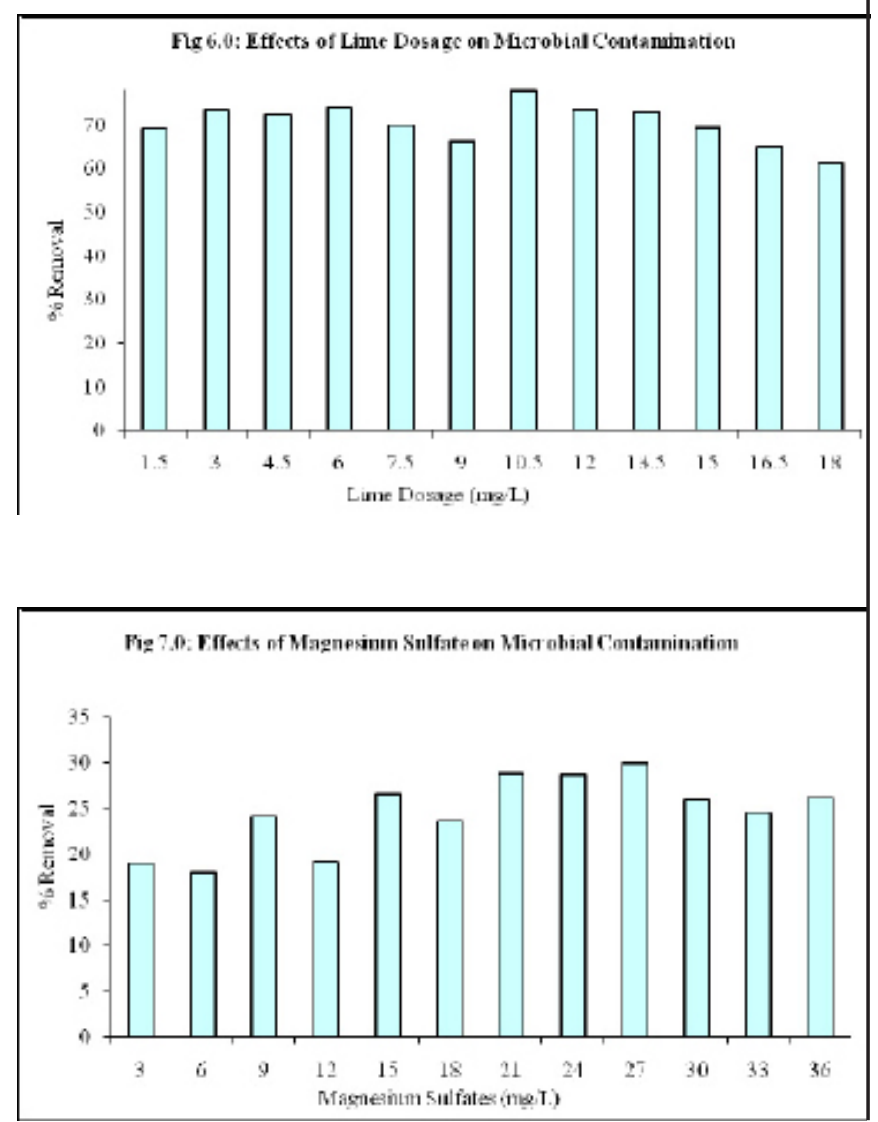

water quality analysis for at least twelve months to study the characteristics changes subjected to seasonal variations and flow rates. Different types of coagulants and filter media should be used to evaluate a better treatability performance.

Engr Arshad is a graduate in Civil Engineering from the University of Engineering and Technology (UET), Taxila, Pakistan. He has done Masters in Environmental Engineering and E-MBA (Environmental Project Management). He has a versatile experience of teaching and research in various institutions and organizations of national and international repute. He has more than ten research publications. Presently, he is serving at Pakistan's National University of Sciences and Technology as an Instructor.

Corresponding address: aliarshado8@yahoo.com

Hashim Nissar Hasim, PhD, is a graduate of Civil Engineering from the University of Engineering and Technology (UET), Taxila, Pakistan. He has completed his doctorate in Water Resources Engineering and Post-Doctorate in Environmental Engineering from UK. He has a rich experience of Civil Engineering. Presently, he is serving in UET Taxila as the Chairman of the Department of Civil and Environmental Engineering.

Corresponding address:drhrh@yahoo.com

Ashfaq Ahmad, Engr., is a graduate pf Civil Engineering from UET Taxila. He has also done a Masters degree in Environmental Engineering from the same university. He has more than six years of professional experience of civil and environmental engineering in govern-ment organizations.

Intikhab A.Q., PhD, is a Civil Engineere and Senior Instructor at the College of Civil En-gineering (MCENUST), Risalpur Cantt, NWFP, Pakistan.

Corresponding address: intikhabahmad@yahoo.com

\section{References}

Holleman, A.F. and E. Wiberg, 2001, Inorganic Chemistry, San Diego, CA: Academic Press.

Lindsten, Don C., 1984, 'Technology transfer: Water purification, U.S. Army to the civilian community,' Journal of Technology Transfer 9(1):57-59.

Masters, Gilbert M., 1998, Introduction to Environmental Engineering (2nd ed.), Upper Saddle River, NJ: Prentice Hall.

Nwachcuku, N. and C.P. Gerba, 2004, 'Emerging water borne pathogens: Can we kill them all?' Current Opinion Biotechnology 15(3):175-180.

Pak-EPA, 1999, Environmental Technology Programme for Industries (Draft Environ-mental Report), Islamabad: Environmental Protection Agency, Pakistan.

West, Larry, 2006, 'World Water Day: A billion people worldwide lack safe drinking water'; URL: environment.about.com.

WHO and UNICEF, n.d., Joint Monitoring Program, Geneva: World Health Organization and New York: United Nations Childrens Fund; URL: www. wssinfo.org (accessed May 2008).

WHO and UNICEF, 2006, Joint Monitoring Programme for Water Supply and Sanitation, Geneva: World Health Organization and New York: United Nations Childrens Fund; URL: www.wssinfo.org (accessed May 2008). 